\title{
ANALISIS RESPON BELAJAR SISWA MENGGUNAKAN TAKSONOMI SOLO MATERI SUHU DAN KALOR
}

\author{
Nidya Desyana \\ Universitas Negeri malang. Malang, 65145 \\ Email Korespondensi: nidya.desyana.1803218@students.um.ac.id \\ Diajukan: 3 January 2020; Diterima: 8 February 2020; Diterbitkan: 30 April 2020

\begin{abstract}
Abstrak: Penelitian ini bertujuan untuk menganalisis respon belajar siswa berdasarkan taksonomi SOLO pada materi suhu dan kalor di SMA Negeri 3 Samarinda. Jenis penelitian yang digunakan adalah penelitian deskriptif. Subjek penelitian ditentukan dengan teknik purposive sampling yaitu kelas X MIA-1 yang berjumlah 32 siswa. Respon belajar siswa dianalisis menggunakan taksonomi SOLO (Structure Of Observed Learning Outcomes) yang terbagi menjadi 5 bagian, yaitu prastruktural, unistruktural, multistruktural, relasional, dan abstrak diperluas. Hasil penelitian menunjukkan respon belajar siswa pada level unistruktural sebesar $87,35 \%$ dengan kategori baik sekali, level multistruktural sebesar $88 \%$ dengan kategori baik sekali, level relasional sebesar $64,10 \%$ dengan kategori cukup, dan level abstrak diperluas sebesar 73,4\% dengan kategori baik.
\end{abstract}

Kata Kunci: Taksonomi SOLO, Respon Belajar Siswa, suhu dan kalor.

Abstract: This study aims to analyze student learning responses based on the SOLO taxonomy on temperature and heat material at SMA Negeri 3 Samarinda. The type of research used is descriptive research. The research subjects were determined by purposive sampling technique, namely class X MIA-1, totaling 32 students. Student learning responses were analyzed using the SOLO (Structure of Observed Learning Outcomes) taxonomy which is divided into 5 parts, namely prestructural, unistructural, multistructural, relational, and expanded abstract. The results showed that student learning responses at the unistructural level were $87.35 \%$ in the very good category, the multistructural level was $88 \%$ in the very good category, the relational level was $64.10 \%$ in the moderate category, and the abstract level was expanded to $73.4 \%$ with good category.

Keywords: SOLO Taxonomy, Student Learning Response, temperature and heat.

\section{Pendahuluan}

Pendidikan abad ke-21 sebaiknya disesuaikan dengan kebutuhan dan tuntutan standar kompetensi terkini. Menurut Framework for 21st Century Learning, siswa harus mempelajari kemampuan yang sesuai dengan kebutuhan saat ini seperti (a) kemampuan berpikir kritis dan pemecahan masalah, (b) kemampuan berkomunikasi, (c) kemampuan mencipta dan memperbarui, (d) kemampuan bekerja sama, (e) kemampuan belajar kontekstual, dan (f) kemampuan literasi informasi dan media (Dede, 2009). Kemampuan tersebut dapat dipenuhi jika siswa memiliki penguasaan konsep yang baik.

Penguasaan konsep siswa dapat diketahui dari respon (jawaban) yang diberikan siswa dalam menyelesaikan soal-soal fisika. Untuk mengukur penguasaan konsep siswa diperlukan suatu asesmen. Asesmen bermanfaat bagi guru untuk memberikan gambaran pengetahuan yang dimiliki siswa.
Sedangkan bagi siswa, asesmen bermanfaat sebagai feedback atas pemahaman yang dimilikinya (Siswaningsih, Dwiyanti, \& Gumilar, 2013). Asesmen yang dilakukan selama pembelajaran juga berpengaruh pada perilaku siswa (Watling \& Ginsburg, 2019).

Asesmen dalam ranah kognitif umumnya dibuat dalam bentuk tes menggunakan taksonomi bloom. Dimensi struktur proses kognitif menurut taksonomi bloom yang telah direvisi terdiri dari ingatan, pemahaman, penerapan, analisis, evaluasi, mencipta (Krathwohl, 2002). Taksonomi bloom dimanfaatkan guru dalam membuat tes penguasaan konsep siswa.

Respon siswa dalam menjawan tes dapat dianalisis menggunakan taksonomi SOLO (Structure Of Observed Learning Outcomes). Kerangka kerja dalam taksonomi SOLO dapat menggambarkan kompleksitas respon yang diberikan siswa (Biggs \& Collis, 1989). Taksonomi ini bermanfaat menentukan level 
respon yang diberikan siswa terhadap suatu pertanyaan. Taksonomi SOLO dapat dijadikan sebagai alternative bagi guru untuk melakukan analisis respon belajar siswa.

Bigg dan Collis secara khusus mengembangkan taksonomi SOLO untuk mengukur level respon belajar siswa ke dalam lima tahap/level, yakni level pra-struktural, unistruktural, multi-struktural, relasional, dan level abstrak diperluas (Biggs \& Collis, 1989). Tingkatan respon berpikir siswa diibaratkan seperti anak tangga yang harus dipanjat siswa selama pembelajaran. Hal ini sesuai dengan teori belajar konstruktivisme dimana siswa harus membangun sendiri pengetahuan dibenaknya dan guru dapat memberikan kemudahan untuk proses ini, dengan memberikan siswa kesempatan untuk menemukan dan menerapkan ide-ide mereka sendiri, dan membelajarkan siswa dengan secara sadar menggunakan strategi mereka sendiri untuk belajar. Guru dapat memberi siswa anak tangga yang membawa siswa ke pemahaman lebih tinggi, dengan catatan siswa sendiri yang harus memanjatnya.

Penelitian pembelajaran yang menggunakan taksonomi SOLO telah dilakukan pada bidang keilmuan sains (Fägerstam \& Blom, 2013), matematika (Fernández, Nieto, \& Mendoza, 2019), dan teknologi (Higgins, McAvinia, O'Leary, \& Ryan, 2019). Namun, penggunakan taksonomi SOLO dalam pembelajaran fisika masih jarang dilakukan khususnya pada materi suhu dan kalor. Padahal, penerapan taksonomi ini membantu guru untuk mengetahui level kognitif masing-masing siswa secara objektif dan terhadap siswa sendiri menbantu mereka untuk menganalisis hasil pekerjaan mereka dan cara memperbaikinya.

Tujuan dari penelitian ini adalah menganalisis respon belajar siswa berdasarkan Taksonomi SOLO (Structure of Observed Learning Outcomes) pada pembelajaran fisika materi suhu dan kalor di SMA Negeri 3 Samarinda. Materi suhu dan kalor dipilih karena mempunyai karakteristik konseptual analisis yang memungkinkan siswa untuk mengaitkan konsep fisika dengan gejala yang dialaminya melalui kemampuan berpikirnya guna menguasai konsep fisika.

\section{Metode Penelitian}

Jenis penelitian yang dilakukan ialah penelitian deskriptif. Subjek penelitian ditentukan dengan teknik purposive sampling yaitu kelas X MIA-1 yang berjumlah 32 siswa. Penelitian dilaksanakan di SMA Negeri 3 Samarinda pada tahun ajaran 2015/2016.

Tes terbagi menjadi empat konsep bagian: suhu dan pemuaian; hubungan kalor, suhu benda dan wujudnya; Azas Black; dan perpindahan kalor. Distribusi soal disajikan pada Tabel 1.

Tabel 1. Level Soal pada Setiap Pokok Bahasan

\begin{tabular}{clllll}
\hline \multirow{2}{*}{ Pokok Bahasan } & \multicolumn{4}{c}{ Level SOLO } \\
\cline { 2 - 6 } & U & M & R & E \\
\hline a. Suhu dan pemuaian & 1 & 1 & - & - \\
\hline b. & $\begin{array}{l}\text { Hubungan kalor, suhu } \\
\text { benda dan wujudnya }\end{array}$ & - & - & 1 & - \\
\hline c. & Azas black & - & 1 & 1 & - \\
\hline d. & Perpindahan kalor & 1 & - & - & 2 \\
\hline Jumlah Soal & & & &
\end{tabular}

Respon belajar siswa diperoleh dari posttest siswa. Tes yang digunakan berbentuk essay berjumlah 8 butir soal. Persentase respon belajar siswa pada setiap pokok bahasan dianalisis berdasarkan level respon pada taksonomi SOLO. Frekuensi pilihan jawaban siswa dihitung berdasarkan persentase banyaknya jawaban siswa yang sesuai dengan level respon yang ditentukan pada setiap nomor soal dengan menggunakan persamaan berikut ini.

$$
A=\frac{X}{n} \times 100 \%
$$

Keterangan:

$\mathrm{A}=$ Persentase respon siswa.

$\mathrm{X}=$ Jumlah siswa yang mencapai level reson yang ditentukan.

$\mathrm{n}=$ Jumlah siswa yang mengikuti tes.

Persentase respon siswa dikategorikan pada Tabel 2 berikut ini.

Tabel 2 . Kategori Respon Siswa.

\begin{tabular}{ll}
\hline Nilai & Predikat \\
\hline 80 ke atas & Baik Sekali \\
$66-79$ & Baik \\
$56-65$ & Cukup \\
$46-55$ & Kurang \\
45 ke bawah & Sangat Kurang
\end{tabular}

(Sudijono, 2006) 


\section{Hasil Penelitian dan Pembahasan}

\section{Hasil Penelitian}

Repon belajar siswa tiap post-test dikumpulkan dan disusun ke dalam peta respon, data tersebut kemudian dianalisis dengan analisis deskriptif persentase dengan cara mencocokkan hasil peta respon dengan kriteria level SOLO yang diinginkan pada tiap soal post-test. Adapun level taksonomi SOLO disingkat sebagai berikut U (Unistruktural), M (Multistruktural), R (Relasional), dan E (Abstrak Diperluas). Setelah dicocokkan dan dijumlah, data tersebut diubah ke dalam bentuk persentase. Dengan menghitung rata-rata persentase level SOLO yang dicapai siswa selama proses penelitian, maka tampak hasilnya pada Tabel 3.

\begin{tabular}{|c|c|c|c|c|c|c|c|c|}
\hline $\begin{array}{l}\text { No } \\
\text { Soal }\end{array}$ & 1 & 2 & 3 & 4 & 5 & 6 & 7 & 8 \\
\hline $\begin{array}{l}\text { Level } \\
\text { SOL } \\
\mathrm{O}\end{array}$ & $\mathrm{U}$ & $\mathrm{U}$ & $\mathrm{M}$ & $M$ & $R$ & $\mathrm{R}$ & $\mathrm{E}$ & $E$ \\
\hline $\begin{array}{l}\text { Jumla } \\
\mathrm{h} \\
\text { Siswa }\end{array}$ & 31 & 25 & 24 & 32 & 22 & 19 & 26 & 21 \\
\hline $\begin{array}{l}\text { Perse } \\
\text { ntase }\end{array}$ & $\begin{array}{l}96, \\
6 \%\end{array}$ & $\begin{array}{l}78, \\
1 \%\end{array}$ & $\begin{array}{l}75 \\
\%\end{array}$ & $\begin{array}{c}10 \\
0 \\
\%\end{array}$ & $\begin{array}{l}68, \\
8 \%\end{array}$ & $\begin{array}{l}59, \\
4 \%\end{array}$ & $\begin{array}{l}81, \\
25 \\
\%\end{array}$ & $\begin{array}{l}65, \\
62 \\
\%\end{array}$ \\
\hline $\begin{array}{l}\text { Rata- } \\
\text { rata } \\
\text { Perse } \\
\text { ntase } \\
\text { setiap } \\
\text { level }\end{array}$ & & & & & & & & \\
\hline $\begin{array}{l}\text { Keter } \\
\text { angan }\end{array}$ & & & & & & & & \\
\hline
\end{tabular}

\section{Pembahasan}

Respon belajar siswa pada pokok bahasan suhu dan kalor selanjutnya dianalisis untuk setiap level taksonomi SOLO pada setiap pertemuan. Berikut merupakan data respon belajar siswa pada setiap pertemuan:

Level Unistruktural

Soal dengan level unistruktural adalah kriteria soal dengan menggunakan sebuah informasi yang jelas dan lansung dari teks soal. Menurut Gilbert (2004), pada level ini beberapa informasi yang diberikan relevan tetapi hanya berisi satu informasi. Level ini meminta siswa agar dapat mengidentifikasikan, mengingat dan melakukan percobaan sederhana. Level ini terdapat pada soal no 1 dan 2. Pada soal nomor 1 siswa diminta menghitung konversi skala termometer. Berdasarkan Tabel 3, hanya 1 siswa yang tidak dapat mengkonversi suhu dari skala celcius ke reamur. Sedangkan pada soal nomor 2, terdapat 7 siswa yang tidak dapat menentukan arah angin ddi daratan dan lautan menggunakan konsep konveksi.

Secara keseluruhan lembar post-test siswa menunjukkan siswa telah memahami makna suhu walaupun masih dalam level dasar, mengkonversi suhu, menentukan jumlah kalor yang terdapat pada suatu zat, namun masih terdapat beberapa siswa hanya menghapal makna dari konveksi sehingga mengalami kendala ketika soal tersebut dibuat dengan versi yang berbeda. Jika dirata-ratakan maka level unistruktural yang telah dicapai siswa adalah $87,35 \%$ dan masuk dalam kategori baik sekali.

Level Multistruktural

Soal dengan level multistruktural menggunakan 2 informasi atau lebih dan terpisah yang termuat dalam teks soal. Menurut Gilbert (2004), pada level ini respon yang diberikan lebih dari satu infomasi yang relevan, tetapi tidak berhubungan satu sama lain. Semua informasi atau data yang diperlukan dapat segera digunakan untuk mendapatkan penyelesaian. Ciri-ciri soal ini ialah membilang, megurutkan, menjelaskan dan menggabungkan. Siswa diharapkan dapat menggunakan beberapa penggal informasi walaupun belum membentuk pemahaman yang komprehensif.

Soal di level ini meminta siswa untuk menjelaskan fungsi celah yang terdapat pada sambungan rel kereta api. Persentase rata-rata level multistruktural yang dicapai siswa adalah $88 \%$ dan masuk dalam kategori baik sekali. Hal ini mengartikan bahwa siswa telah mampu untuk menjelaskan konsep, mengerti mengerti maksud dari konsep tersebut dan menerjemahkan dengan bahasanya sendiri mengenai konsep yang diajarkan.

Level Relasional

Soal dengan level relasional merupakan kategori soal yang menggunakan suatu pemahaman dari dua atau lebih informasi pada teks dan mengaitnya dengan kesatuan yang padu. Respon yang diberikan lebih dari satu informasi dan berhubungan dengan 
menggunakan gagasan atau hipotesis yang sama tetapi kurang kritis (Gilbert, 2004). Ciri dari level ini ialah membandingkan, membedakan, menganalisis, mengaplikiasi dan menghubungkan. Jika siswa telah mencapai level relasional maka siswa dapat menghubungkan antar fakta dengan teori serta tindakan dan tujuan. Siswa mampu memadukan beberapa informasi terpisah dan menghasilkan penyelesaian.

Pada level ini, siswa diminta menghitung suhu campuran menggunakan persamaan Azas Black. Jika dirata-ratakan maka persentase siswa yang mencapai level relasional adalah $64,1 \%$ dan masuk dalam kategori cukup.

\section{Level Abstrak Diperluas}

Soal dengan level abstrak diperluas berisikan pertanyaan dengan kriteria menggunakan prinsip umum yang abstrak atau hipotesis yang diturunkan dari informasi dalam teks soal. Semua informasi atau data diberikan, tetapi belum bisa segera digunakan untuk mendapatkan penyelesaian akhir. Dari data atau informasi yang diberikan itu masih diperlukan prinsip umum yang lebih abstrak atau menggunakan hipotesis untuk mengaitkannya sehingga mendapatkan informasi atau data baru. Dari data baru ini kemudian diperoleh penyelesaian akhir. Ciri-ciri dari level ini ialah membuat suatu teori, membuat hipotesis, membuat generalisasi, membuat refleksi, serta membangun suatu konsep. Level ini menuntut siswa melakukan koneksi tidak hanya sebatas pada konsep-konsep yang sudah diberikan saja melainkan dengan konsep-konsep di luar itu. Dapat membuat generalisasi serta dapat melakukan sebuah perumpamaanperumpamaan pada situasi-situasi spesifik. Siswa tersebut dapat menghasilkan prinsip umum dari data terpadu yang dapat diterapkan untuk situasi baru (mempelajari konsep tingkat tinggi). Soal dengan level ini diberikan terdapat pada nomor 7 dan 8 .

Rata-rata respon belajar siswa pada level abstrak diperluas adalah $73,4 \%$ dan masuk dalam kategori baik. Sebagian kecil siswa yang belum mencapai level ini dikarenakan siswa belum maksimal dalam memahami materi yang dijelaskan sehingga ada beberapa poin penting yang tidak disampaikan dalam jawaban membuat skor atau nilai siswa menjadi kurang maksimal. Selain itu, waktu pengerjaan soal yang terbatas tidak digunakan secara efektif oleh siswa. Siswa hanya terfokus pada soal tertentu sehingga terdapat beberapa siswa yang mengosongkan jawabannya.

\section{Simpulan, Saran, dan Rekomendasi}

Berdasarkan hasil penelitian, analisa data, dan pembahasan yang telah dilakukan mengenai analisis respon belajar siswa berdasarkan taksonomi SOLO Negeri 3 Samarinda kelas X-MIA 1, maka dapat disimpulkan bahwa: respon siswa pada level unistruktural sebesar $87,35 \%$ dengan kategori baik sekali, level multistruktural sebesar $88 \%$ dengan kategori baik sekali, level relasional sebesar $64,10 \%$ dengan kategori cukup, dan level abstrak diperluas sebesar 73,4\% dengan kategori baik.

Berdasarkan refleksi terhadap penelitian yang telah dilakukan penggunaan taksonomi SOLO dalam menganalisis level respon siswa dapat dikreasikan dengan penggunan instrumen tes yang berbeda, contohnya pilihan ganda beralasan, penggunaan soal isomorpik, dan soal three tier.

\section{Daftar Pustaka}

Biggs, J., \& Collis, K. (1989). Towards a Model of School-based Curriculum Development and Assessment Using the SOLO Taxonomy. Australian Journal of Education, 33(2), 151163.

https://doi.org/10.1177/1687814089033002 05

Dede, C. (2009). Comparing Frameworks for "21st Century Skills." 16.

Fägerstam, E., \& Blom, J. (2013). Learning biology and mathematics outdoors: Effects and attitudes in a Swedish high school context. Journal of Adventure Education and Outdoor Learning, 13(1), 56-75. https://doi.org/10.1080/14729679.2011.647 432

Fernández, E., Nieto, Z., \& Mendoza, L. (2019). Styles of reasoning according to the taxonomy structure of observed learning outcome of John Biggs in the students of geometry of the specialty of mathematics. Journal of Physics: Conference Series, 1329, 012005. https://doi.org/10.1088/17426596/1329/1/012005

Gilbert, R. (2004). Studying Society and Environment: A Guide for Teachers.

Higgins, C., McAvinia, C., O’Leary, C., \& Ryan, B. J. (2019). A Study Of First Year 
Undergraduate Computing Students' Experience Of Learning Software Development In The Absence Of A Software Development Process. Conference Papers. Retrieved from https://arrow.dit.ie/schfsehcon/27

Krathwohl, D. R. (2002). A Revision of Bloom's Taxonomy: An Overview. Theory Into Practice, 41(4), 212-218. https://doi.org/10.1207/s15430421tip4104_2 Siswaningsih, W., Dwiyanti, G., \& Gumilar, C. (2013). Penerapan Peer Assessment dan Self Assessment pada Tes Formatif Hidrokarbon untuk Feedback Siswa SMA Kelas X. Jurnal Pengajaran MIPA, 18(1), 107-115. https://doi.org/10.18269/jpmipa.v18i1.263

Sudijono, A. (2006). Pengantar Evaluasi Pendidikan. Jakarta: PT Raja Grafindo Persada.

Watling, C. J., \& Ginsburg, S. (2019). Assessment, feedback and the alchemy of learning. Medical Education, 53(1), 76-85. https://doi.org/10.1111/medu.13645 